the generosity of APSA members, the maximum award for any grant will be $\$ 300$ and must be used for travel to the meeting. Grants will be awarded in two categories: (1) international graduate students attending U.S. institutions and (2) advanced American graduate students presenting a paper or poster on the Program.

Applicants must complete a short application and submit a letter of support prepared by their department chair. Applications without a letter of support will not be considered. Applicants who are furthest along in their course of study will be given greatest consideration. Previous winner are not eligible.

Applications are available in PDF format on the APSA web site at www.apsanet.org/98AM/Travel/or by contacting Sean Twombly at twombly@apsanet.org. The deadline for receipt of completed applications is July 3 .

\section{Women's Caucus for Political Science to Host Reception for Women of Color Graduate Students}

The Women's Caucus for Political Science and its Women of Color Committee will host its fourth annual reception honoring women of color graduate students in political science Thursday, September 3, 1998 at $6: 30 \mathrm{pm}$ at the APSA's 94th Annual Meeting in Boston. The reception will be cosponsored by the National Conference of Black Political Scientists and the Committee on the Status of Latina/os in the Profession. All APSA members are cordially invited to attend.

The reception provides an occasion for graduate students and faculty from different universities to meet one another, share common interests, and discover the diversity of perspectives and research interests that women of color have in the profession. The Women's Caucus hopes that the event will help alleviate the isolation some women of color might feel and furnish the opportunity to discover colleagues whose scholarly and personal sup- port will enrich their work as political scientists.

\section{Pi Sigma Alpha Joins APSA in Recognizing Teaching; Sponsors Annual Meeting Panel}

Pi Sigma Alpha, the National Political Science Honor Society, recently announced its cosponsorship of APSA's teaching awards, beginning at the 1998 Annual Meeting. Since 1993 the Association has paid tribute to political science teachers whose own colleges and universities have selected them for institutionwide recognition with a special Annual Meeting Honors Reception. The 1998 event will take place on Wednesday, September 2 at 6:00 p.m. in Boston.

To shed light on the development of unconventional classroom teaching methods, $\Pi \Sigma A$ will present a panel at the Annual Meeting on using simulation techniques for teaching political decision making. "Simulating Politics: Bringing the Drama of Conflict into the Undergraduate Classroom" will be chaired by Jeremy D. Mayer of Kalamazoo College and will feature papers by Mayer; Marcia Weigel, Bowdoin College; Ashlyn Kuersten, Western Michigan University; and Christopher C. Joyner and Tamara Cofman Wittes, Georgetown University. The discussants are Claudia Orenstein of the drama department at Barnard College, and political scientist Eric Siegel of the University of California, Davis.
For more about Pi Sigma Alpha and its programs, including information on how to start a chapter of the honor society on your campus, please contact the national office at Pi Sigma Alpha National Office, 1527 New Hampshire Ave., NW, Washington, DC 20036; Phone: (202) 483-2512; Email: pisigmaa@erols.com, or visit their web site at http://www.apsanet.org/ $\sim$ psa.

\section{Sapiro Represents APSA at British Meeting}

Virginia Sapiro, Sophonisba P. Breckenridge Professor of Political Science at the University of Wisconsin, Madison attended the annual meeting of the British Political Studies Association (PSA) in April as the official representative of the APSA. Spairo, Program Chair for the 1998 APSA Annual Meeting, delivered the opening Plenary Session lecture, "A History of Political Action in the United States."

Sapiro's participation marks a further step in a growing collaboration between the APSA and PSA. As part of an agreed exchange program, official representatives of the PSA will attend the APSA meeting in Boston later this year to discuss further efforts. The first major effort of the collaboration was the inclusion of British graduate programs in the 1998-2000 edition of the APSA's Graduate Faculty and Programs in Political Science.

\title{
National Teaching Award for Political Scientists to Be Given for Second Year
}

Rowman \& Littlefield established the Rowman \& Littlefield Award for Innovative Teaching in Political Science in 1997 to recognize political scientists who have developed effective new approaches to teaching in the discipline. The award, which carries a $\$ 500$ stipend, will be presented at the 1998 Honors Reception at the APSA Annual Meeting. This year's recipient will be chosen by a committee consisting of L. Sandy Maisel, Colby College (Chair); Kent Portney, Tufts University; Susette Talarico, University of Georgia; Kim Zisk, Barnard College; and Sheilah Mann, APSA (ex-officio). The deadline for nominations was February 15, 1998. 